\title{
FORESEEING THE PAST: PROBABILITY AND ANCIENT GREEK DECISION-MAKING
}

\author{
By Paul Vădan
}

"Probability does not exist."

- Bruno de Finetti

Summary: The article explores the concept of probability in ancient Greece from a nonscientific perspective and shows how ancient decision-makers used historical data to make calculated decisions and speculate about the future. First, the paper considers how quantitative data was used by ancient Greek communities to make economic projections. It then shows how ancient Greek generals used the same conceptual tools to determine their odds of victory by tallying up and comparing the number and composition of armies and resources available to them and their enemy. In the third section, the paper examines how qualitative probability was articulated through the language of hope and likelihood to formulate chances of success in moments of crisis. Finally, the paper shows that ancient decision-makers implemented "power laws" to adapt to changing circumstances and the flow of new information, as they sought to improve their odds of success relative to their rivals.

\section{INTRODUCTION}

In his published conversations with Christopher Pierson, sociologist Anthony Giddens contends that human history turned "modern" when the mathematical discoveries of the 16th century set the foundations of the sciences of statistics and probability. ${ }^{1}$ For the first time in human

* I am grateful to Alain Bresson and Paul T. Keyser for their time and generous comments at various stages in the paper's development. Caitlin Miller's proofreading and suggestions have improved the clarity and structure of this paper. I would also like to thank the organizers and participants of the Ancient Societies Workshop at the University of Chicago, whose questions and suggestions have helped me strengthen

Paul Vădan 'Foreseeing the Past: Probability and Ancient Greek Decision-Making' C\&M 70 (2022) 17-58. 
history, human actors could quantify uncertainty and think about the future through the modern concept of risk. Giddens could thus announce that "risk has replaced fortuna," 2 confident that the "modern" enlightened world has finally managed to shed the old superstitions of "traditional" societies by relying on the rational and "novel" sciences of statistics and probability to quantify, predict, and control an otherwise dangerous future.

Giddens' thesis has been influential in the study of sociology, and has also impacted the way classicists approach ancient decision-making. Notably, Mary Beard has characterized the Graeco-Roman world as an "aleatory society," where the model of gambling luck governed the way the ancients approached danger. For Beard, "Rome was a culture that looked danger in the eye. It did not attempt to avert or calculate danger, but rather to assert (almost celebrate) the uncertainties, chances and dangers of human existence." ${ }^{3}$ Her interpretation takes the form of a verdict that relegates ancient considerations of danger to the narrow and morally-charged concern with daring, "[facing] danger head-on," since "anything like a calculation of the probability of danger, let alone a recognisable risk agenda," ${ }^{4}$ was absent in antiquity.

In fact, recent scholarly attempts to talk about ancient "risk-taking" have been countered by the same scientific argument pointing to the absence of mathematical probability in antiquity. For instance, Esther Eidinow's (2007) non-quantitative approach to ancient Greek

my argument. Finally, I benefited from conversations on ancient risk with Anna Francesca Bonnell-Freidin, Esther Eidinow, Stephen Kidd, and Brent Shaw.

1 Giddens describes the modern world as "vastly more dynamic than any previous type of social order. It is a society - more technically, a complex of institutions which unlike any preceding culture lives in the future rather than in the past." Giddens \& Pierson 1998: 94. Similar arguments for a conceptual divide between antiquity and modernity have been promoted by Christian Meier (1990), who argued that the modern concept of "the State" was absent in antiquity. Also, Reinhart Koselleck (2006) has argued that the modern idea of "crisis" referring to a political and economic event was not found in the ancient notion of kpíбı; the argument has been disputed by Kuin \& Klooster 2020: 3-14.

2 Giddens 1990: 30.

3 Beard 2011: 98.

4 Beard 2011: 91, 98. 
perceptions of risk has been critiqued by classically-trained sociologist of religions Kim Beerden (2013), who questions Eidinow's use of the term "risk" as a modern imposition upon antiquity. Referencing Giddens' work, Beerden considers risk as intimately linked to the modern sciences of statistics and probability, whereas "all [ancient Greek] expressions of thinking about the future differ crucially from modern conceptions of risk: there was no calculation of the chances or probability of disaster or success"; the ancients had to content themselves only with divination. ${ }^{5}$

However, this modernist sociological attitude to risk and decisionmaking carries with it an insidious claim: namely, that the modern world's response to crisis is, in some sense, original, where contemporary issues have contemporary solutions. It follows that ancient experiences and crisis-solving mechanisms are no longer helpful, being relegated to the categories of superstition and credulity. What is more, this sociological insistence on technological progress as a marker of cognitive ability is less than truly explanatory, if not morally dubious, and attracts simplistic value judgments. Take, for instance, sociologist and philosopher Niklas Luhmann's (1991) comment on the seeming absence of mathematical probability in antiquity, that Greek ingenuity had finally reached its limits, unable to explore futurity beyond the use of cosmology and a passive acceptance of divine agency.

Likewise, economist Peter Bernstein (1996) deemed the failure of "the Greeks" to engage with probability theory as "astonishing," concluding that "despite the emphasis that the Greeks placed on theory, they had little interest in applying it to any kind of technology that would have changed their views of the manageability of the future." Bernstein adds that only after the mathematical revolution sparked by Pascal and Fermat did views about gambling move beyond ancient and outdated conceptions of chance: "The act of risk-taking floated free, untrammeled by the theory of risk management." ${ }^{6}$ Consequently, ancient societies are denied a fundamental level of cognitive rationality, institutional complexity, and individual agency to anticipate, assess, and mitigate potential dangers.

5 Beerden 2013: 202.

6 Bernstein 1996: 11, 16. 
And yet, as I will show in this article, the extant evidence pertaining to ancient decision-making counteracts these primitivist sociological attitudes towards the ancient world. Indeed, if we expand our enquiry beyond the narrow constraints of ancient mathematics, we find different strategies by which ancient decision-makers formulated and applied probabilistic thinking to quantify uncertainty and inform collective economic, social, and military decisions. To do so, I specifically focus on literary evidence from the 4 th century BCE onwards when ancient thinkers started theorizing about probabilistic thinking in a systematic way by prescribing codes of behavior and systems of knowledge to calculate the future. I first show that in the absence of conclusive evidence pertaining to ancient mathematical probability, we nevertheless have instances where ancient decision-makers used abstract numbers to express odds of success about economic and military risks. I then assess the qualitative language of likelihood used by ancient decision-makers to assign gradations of risk to dangerous events. Finally, I turn to the use of the past by military leaders to imagine historical precedents to present circumstances as a way to generate statistical data and shape collective expectations about the future. In doing so, I bridge the conceptual divide between antiquity and modernity by highlighting the culturally-specific character of the concept of probability.

\section{ANCIENT PROBABILITY AS A METHODOLOGICAL PROBLEM}

The narrative that probability is an inherently modern product of Enlightnement mathematicians has recently been dismissed by statistician Glenn Shafer (2018) as mere legend. Schafer assigns responsibility to the work of Ian Hacking (1975 and 1990) for further popularizing the notion that these polymaths were responsible for combining, for the first time, the philosophical ideas of belief and frequency. ${ }^{7}$ He points to pre-existing evidence collected by Marie-France Bru and Bernard Bru (2018), some from Arabic texts, discussing dice games and contracts that express probabilistic logic. An imporant

7 Shafer 2018: 279. 
instance is the famous 13 th century CE poem De Vetula, ${ }^{8}$ whose author is clearly aware that some arrangements in dice games do not have the same force or frequency, whose complexity has been deemed by the Brus (2018) a veritable "calcul de chances." For Shafer, such texts indicate an understanding of the character of probabiliy as the union between belief (betting) and frequency (outcome). ${ }^{10}$

Nevertheless, Hacking has often defended his thesis from such criticisms by stating that "what is important is not the occurrence of a few probability ideas in antique texts but a use for them, a use that spans morals, politics, economics and social affairs, and which engenders a new era of conjecturing on the one hand and a new mode of representing reality on the other." 11 This statement, however, is unfair to both ancient and modern thinkers alike because the act of choosing a "birth moment" for a concept is a misleading exercise. ${ }^{12}$ For the sake of argument, one could just as easily claim that the real revolution in statistics and probability theory came not in the 17th century, but much later in 1933, when Andrei Kolmogorov laid the axiomatic foundations of probability theory by publishing his Grundbegriffe der Wahrscheinlichkeitsrechnung. ${ }^{13}$ Kolmogorov's achievement eventually allowed the application of probability theory to solve economic problems, but only after World War II, when it was gradually employed in the modern financial system. That, however, would deny Cardano, Pascal, Fermat and all of Kolmogorov's predecessors the cognitive capacity to think axiomatically about probability theory, which would be both unfair and misleading.

And yet, while medievalists have been quick to take up Hacking's challenge by highlighting the complex probabilistic character of so-

8 For a discussion on calculating permutations in ps.-Ovid's De Vetula, see Kidd 2020: 19-20.

9 Bur \& Bru 2018: 306.

10 Shafer 2018: 280.

11 Hacking 1975: 108.

12 Similar arguments have been made against the presumed modern origin of concepts like "crisis" (Kuin \& Klooster 2020), "intuition” (Struck 2016), "landscape” (Zientek 2014) and "risk" (Vădan 2018).

13 Shafer \& Vovk 2001: 39: “Among mathematicians, its simplicity, clarity, and power made it the easy victor in the spirited debate on the foundations of probability that took place in the 1930s." 
called "aleatory contracts," 14 classicists have instead limited themselves to justifying the ostensibly rudimentary character of ancient theoretical mathematics. In a recent article on ancient gambling, Stephen Kidd (2020) has sought to account for the apparent absence of mathematical probability in antiquity by looking at the character of games that ancient gamblers played: whereas modern gamblers play games that require them to take individual risky bets based on personal calculations, ancient gamblers, by contrast, played games with previously agreed-upon group wagers, which rendered risk a communal affair. The result, Kidd explains, is that "the incentives to calculate such probable outcomes were not at all glaring, since there was simply no gambling game to which such calculations would have been applicable." 15 According to this argument, we would have to wait until the 16th century when gamblers finally had the incentive to calculate their individual gambling risks for profit, which would eventually lead them to ponder the theory of probability: "with new games to play, people began to think in a new way. That new form of thinking gave rise to mathematical probability and the related field of statistics."16

Kidd's analysis of ancient games is impressive and highlights the importance of incentives to finding new solutions to old problems. He is also right to point out the cumulative, rather than individualistic, character of technological progress. But as is often the case, the presumed absence of a certain kind of technology does not necessarily

14 Hald 2003: 32: "The basis of such contracts became the specification of conditions for the equity of the parties involved, which required assessment of risks combined with the possible gains and losses." For the theological and legal aspects of risk-taking in the development of the concept of expectation in probability theory, see also Coumet (1970), Daston (1980), and Schneider (1980).

15 Kidd 2020: 3, 5. It is worth noting that while Kidd (n. 16) acknowledges that ancients tried to get an advantage in dicing through cheating, he does not connect this phenomenon with the possibility of probabilistic thinking. However, Jerzy Neyman (1976: 152) has interpreted tampered dice as an awareness by the cheater of the important phenomenon of long-run frequency. He mentions loaded dice found in Egyptian Pharaonic burial chambers, suggesting that such an understanding of dice is as old as dicing itself.

16 Kidd 2020: 22. 
entail the absence of ideas about it. ${ }^{17}$ In fact, scholars have recently made the case that even modern technological industrial discoveries generally rely on non-scientific rather than scientific processes. ${ }^{18}$ Likewise, the absence of evidence poses a methodological challenge to historians because it does not automatically discard the possibility that such evidence did - or does - exist. Kidd's argument thus needs to be considered with caution because it relies in part on the (supposed) silence of the evidence. To this point, shafer is confident that there remains the real possibility of discovering ancient manuscripts detailing probabilistic thinking, especially in the oft-ignored Arabic manuscripts. Indeed, Reviel Netz (2016) has estimated that "we have attested something like $20 \%$ of ancient mathematical authors, and have extant something like 3\%-5\% of ancient mathematical texts." 19 There thus remains the real possibility that some of them may have explored mathematical probability, as hinted at by a variety of philosophical works that touch on the subject, if only in a rudimentary way. ${ }^{20}$ In fact, it has been argued that the rise and rule of Rome negatively impacted scientific innovation, with the number of mathematicians and scientists regularly decreasing during the Roman empire, until finally becoming

17 One notable example is the development of the abstract principles of thermodynamics by Nicolas Carnot in the 1820s, one century after the implantation of Newcomen's steam engine (Mokyr 2009: 124-44). From a different perspective on the ancient Greek world, John K. Davies (2003) approached Athenian democracy through systems analysis to explain its development in the 5th century BCE in the absence of a general Athenian political theory. Likewise, Josiah Ober (2008) showed how Athenian institutions allowed for the spread of knowledge needed by novice office holders to govern the state through "demotic clusters" of administrative memory, despite the absence of complex information networks.

18 Bresson 2014: 67. See also Clark 2012 for the "idealist" model, and Allen 2009.

19 Netz 2016: 85. Bru \& Bru 2018: 302 also agree that we may yet unearth ancient Babylonian tablets or Egyptian papyri that explore the concept of probability.

20 Keyser \& Scarborough 2018; Keyser \& Irby-Massie 2002. For instance, we know of Xenokrates of Chalkedon's now-lost work on combinatorics, entitled On Numbers. In contrast, most claims on ancient statistics focus almost exclusively on the rudimentary observations of Cicero and Aristotle on dice and numbers, without considering the historical implications that these writers were not known as mathematicians, whose observations on the topic were perhaps influenced by other works. Cic. Div. 1.23, 2.48, 2.121; Arist. Cael. 2.12 (292a30), PN 463b19-23, 3.4.1407b1. 
negligible in the fifth century $\mathrm{CE},{ }^{21}$ leading Alain Bresson (2014) to describe the history of Greek science as an interrupted process. ${ }^{22}$ We can thus imagine a scenario where diminishing interest in theoretical science would have discouraged further innovation, which then compounded the problem of manuscript preservation, some of whom still surviving in Arabic texts that have yet been discovered, read, or even translated.

Even so, I suggest that we can bypass the problem of missing mathematical evidence by looking at instances of probabilistic thinking beyond mathematics. To do so, we need to expand our understanding of probability beyond the notion of a closed system governed by symmetry and abstract logic where numerical odds can be objectively calculated. This so-called "classical symmetry" model implies that probability theory could have only developed in a very specific historical context like gambling, whereas statistician David Spiegelhalter (2011) explains that "classical symmetry" is but one way to think about assigning probabilities to events. When it comes to real-world circumstances, Spiegelhalter points out that another means to quantify uncertainty is to use historical data, the so-called "frequentist" method: "If the future follows the same pattern as the past, then frequencies of events in history should reflect reasonable probabilities for events in the future," thus rendering potential responses and outcomes to present circumstance rather predictable. ${ }^{23}$

Mathematician and philosopher James Franklin (2001) concurs that probability in the modern form did not develop earlier in part for the simple reason that dice and other "classical symmetry" tools are not a reliable model to tackle real-world situations. ${ }^{24}$ Richard Thaler (2015) illustrates this problem succintly by distinguishing between "Econs" and "Humans," where Econs are fully "rational" optimizers when it comes to economic theory. By contrast, Humans "misbehave" according to beliefs, instincts, and patterns of thought that are decidedly non-optimal. And since we do not live in a world of Econs but in a world of Humans, Thaler

21 Keyser 2010.

22 Bresson 2014: 68-69.

23 Spiegelhalter 2011: 19.

24 Franklin 2001: 334. 
asserts that culturally-specific Human behaviors and experiences need to be considered when building theoretical models. For our purposes, Thaler's approach is important because it also implies that one does not necessarily need to be versed in economic theory to behave economically by counting on historical data and personal experience, if not always precisely. ${ }^{25}$ Accordingly, I will show that the nature and contents of our sources speak to a Hellenistic interest in using historical data in social, political, and economic contexts other than gambling, to make calculated decisions and speculate about the future. As such, in the presumed absence of an ancient theory of probability, we can interpret the ancient evidence through a frequentist approach to identify clear instances of the philosophical concept of probability.

\section{QUANTITATIVE PROBABILITY AND THE ANCIENT ECONOMY}

Ancient economic practices offer several illuminating instances of quantitative probability based on experience and historical data. At a fundamental level, agricultural production relied on risk-mitigating strategies meant to offset periods of wide climatic variation, with rainfall alternating sharply between wet and dry phases, which would have otherwise made it difficult to estimate yields and plan for the future. ${ }^{26}$ As ancient economists have already pointed out, diversification of crops and polyculture, the building of waterworks, together with sharecropping contracts, were some of the ways in which landowners sought to control the uncertainty of an irregular climate..$^{27}$ These efforts

25 Thaler 2015: 2-12.

26 Sallares 1991: 393-95, building on the work of Peter Garnsey (1988), who has shown that despite regular crop failure, poleis generally did not experience famine due to various social and economic measures implemented. These included setting up reserves, price moderation, and patronage.

27 Thomas Gallant (1991) provides a general overview of the resource strategies that Greek households would implement to deal with shortfalls in production. He illustrates how an agricultural system could adapt to the pressures of land life cycles 
were aimed at absorbing the potential risk of resource scarcity in the chora, which in turn helped a community make better predictions about future agricultural yields.

Following the same logic, ancient communities implemented various financial schemes to regulate public funds in an economic crisis. A somewhat morbid case study is offered by a Milesian inscription recording a public decision to create an annuity fund sometime in 211/210 BCE to incentivize wealthy individuals to facilitate public investment:

The Milesians have voted that those male or female citizens who wish to give 3,600 drachmas on behalf of themselves or on behalf of others [...]. In return for the money given to the city, each of the donors shall receive thirty drachmas per month from the city, for as long as they live. This money shall be given each year by the treasurers, withdrawing and distributing the money, in the same way as is prescribed in the laws for the priests and those who have won contests in games with a prize of crowns. ${ }^{28}$

The initiative attracted no less than thirty-nine contributions from thirty-four individuals, who could recuperate their money within ten years. ${ }^{29}$ There was, however, a catch: "If any of those who gave the proposed amount to the city depart from life, the people shall be released from repaying the donation and the reserved annuity, but one hundred

through strategies of crop diversification, intercropping, irrigation, and fragmentation of land holdings. On more detailed examples from the Roman world, see the more recent work of Bruce Frier (2007) and Dennis Kehoe (2007).

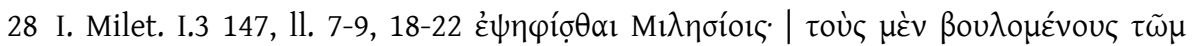

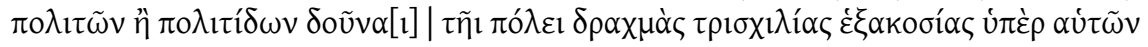

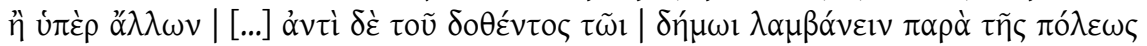

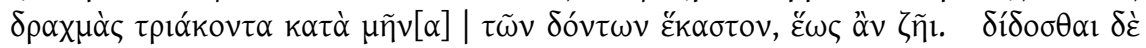

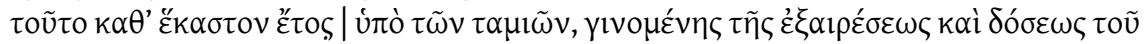

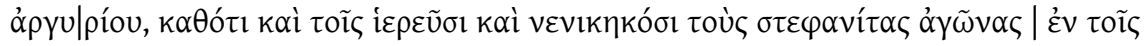

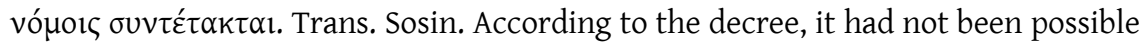
for the city to collect an eisphora due to lack of funds and revenues; contra Franklin 2001: 259.

29 Recorded at Milet I.3 147, 11. 87-104. 
and fifty drachmas shall be given to the relatives of each of them for their burial." ${ }^{30}$ Joshua Sosin (2014) interprets this "death clause" in the annuity contract as an attempt at financial speculation: if the state bank were to invest the collected money at a common rate of $12 \%$ per year, "the fund would have yielded Miletos a meager 2,808 drachmas annually, until the beneficiaries started to die out; every death tipped the scale in the state's favor." ${ }^{31}$ The demos, therefore, made a long-term bet whose value was directly correlated to the probability that older wealthier individuals would die before they would collect all the money they had made available for the public.

And while the study of ancient demography and mortality rates is beyond the scope of this article, it is worth noting that we have evidence from the Roman Empire of early attempts to calculate annuities based on life expectancy. The so-called "Ulpian's Life Table" has been interpreted to represent the calculation of annuity premiums with an interest rate of about $1.5 \%$ based on age, which has helped scholars approximate a life expectancy of 40 years for someone aged $20 .^{32}$ These numbers have been disputed, but scholars agree that we are looking at a crude annuity table. Returning to the Miletos decree, it is clear from its clauses that rich Milesians were themselves aware of the unavoidable mortality problem. They took advantage of a special representation clause, which perhaps they themselves maneuvered to have included in the decree, which stipulated that:

if anyone registers the name of another male or female citizen, he shall be given the resulting annuity for as long as those registered are

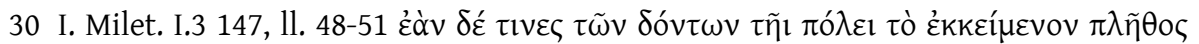

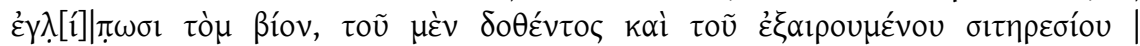

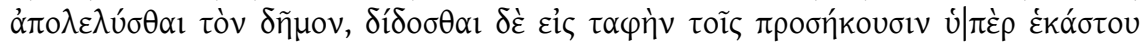
$\delta \rho \alpha \chi \mu \grave{\alpha} \varsigma \dot{\varepsilon} \kappa \alpha \tau o ̀ v ~ \pi \varepsilon v \tau \eta ́ \kappa o v \tau \alpha$. Trans. Sosin.

31 Sosin 2014: 80.

32 Pflaumer 2015: 2677-78; though his numbers are slightly different from DuncanJones (1990: 94, 100-1), who suggests a life expectancy of 32 years from someone aged 25 , and that the beneficiaries of the life-annuities were slaves or ex-slaves, and not Roman elites. See also Frier 1982 and 2018 for a close analysis of the Ulpian Life Table and the projected life expectancy for both Roman men and women. See also Cicero's observations on different mortality rates between youths and adults (Cic. Sen. 19). 
alive. If the one who registered the name dies first, then the one whose name was registered shall receive the reserved annuity for the remainder of the time. ${ }^{33}$

The clause was a way for rich families to bypass the "death clause" and recoup their investment within ten years and, furthermore, to continue to make a profit beyond that point. Sosin's analysis of the names of the benefactors and their beneficiaries highlights the point that "Milesians were not demographers, but they could do the math," explaining that "of all of the donations, roughly two thirds were made on behalf of a younger beneficiary or else by a young beneficiary on his or her own behalf." ${ }^{34}$ The inscription, therefore, is a classic example of the rich getting richer at the expense of the state during times of general financial hardship. But the greater point is that both the state and its wealthy families used their understanding of life expectancy to make more predictable financial speculations. ${ }^{35}$

Financial incentives to quantify uncertainty also defined how ancient trade was conducted. Alain Bresson (2004 and 2016) has analyzed ancient insurance practices to show how investors quantified danger. He concludes that interest rates were directly correlated to the risk of

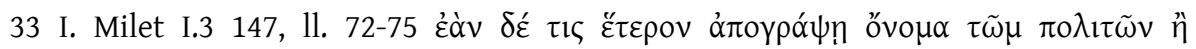

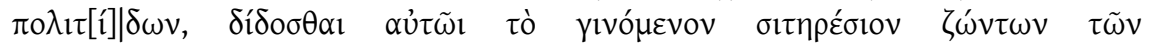

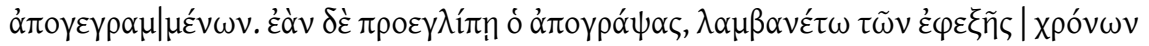

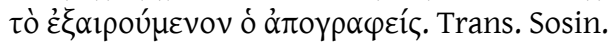

34 Of the 39 donations, 22 were made on behalf of others, most probably sons and daughters, and of the 17 who contributed in their own names, two were females under the kyrieia of men not said to be their husbands, and so perhaps orphaned minors, and two were male minors. Sosin 2014: 81.

35 Other epigraphic examples of financial speculation include Austin 115, where the Olbians honor their benefactor Protogenes for, among other things, helping them purchase grain at a decent price, after correctly speculating that the price of a medimnos would increase exponentially: "Again in the priesthood of Plistarchus, when there was a severe shortage of corn and / grain was being sold at a medimnos and 60 two thirds for a gold coin, and it was clear that the price would rise further, and in fact the medimnos immediately reached the price of one gold coin and two thirds" (1l. 58-64). For an analysis of the financial crisis at Olbia, see Müller 2011. See also, Austin 118 where we get a glimpse into the public budget of Halikarnassos that includes a debt repayment plan and future funds to be earmarked for public works. 
shipwreck, which was known to lenders from historical data. ${ }^{36}$ Estimations were precise enough to not only evaluate total damages but also to distinguish the number of shipwrecks in connection to the time of the year: while at the beginning of the sailing season one could expect one ship in five to sink, at the end of the season the chances could be as high as one in three. ${ }^{37}$ Literary evidence corroborates these finds, as we learn from the description of a maritime loan contract in Demosthenes' Against Lakritos that interest rates regularly changed in accordance with the time of the year: during the high sailing season, interest was estimated at $22 \%$, while after the rising of Arktouros the rate could go as high as $30 \%{ }^{38}$ Demosthenes thus provides us with a glimpse into the intricate ancient practice of putting numbers on uncertainty that determined the future behavior of traders and investors. Indeed, as Edward Cohen has shown, "maritime yields" were determined by contractual agreements that took into account the degree of risk and anticipated profitability of a trading venture. ${ }^{39}$ Contracts thus anticipated a variety of circumstances and contingencies pertaining to the itinerary and the inter-personal trust involved in the trading venture. ${ }^{40}$ Given that the entire maritime commercial infrastructure relied on credit, creditors made profits from transactions where high

36 On the economic and insurance information that can be teased out from shipwrecks, see Gibbins 2001; Bresson 2016: 89-90, 283-84.

37 The economic system was based on acquired experience and shared knowledge of everyone involved in maritime trading, making it possible to stimulate trade while also diminishing the inevitable risks of seafaring for everyone involved; a business practice now known as "risk pooling" (Bresson 2016: 280-83).

38 Bresson and Bresson 2004: 8-9. By also looking at grain trade prices, the Bressons further explain how the leverage investment system made borrowing preferable for the trader because he did not have to put his whole fortune at stake. We may also note the treatise De Contractibus by the Franciscan monk Olivi in the 13th century, that assigns numerical values to the perceived risk of maritime insurance contracts. For Marie-France and Bernard Bru, Olivi's calculations of gains and risk are comparable to those of the founders of the insurance science in the 20th century. Bru \& Bru 2018: 320.

39 Cohen 1992: 53-55.

40 Using New Institutional Economics, Vincent Gabrielsen shows how the ancient Greek state promoted systems of trust and information sharing that resulted in lower transaction costs (Gabrielsen 2016: 87). 
risks yielded high rewards, which in turn allowed them to absorb the risk of an individual disaster like the sinking of a ship. ${ }^{41}$

These trading ventures thus speak to the complex interplay between collective and individual risk. Like in a game of dice, the risk was indeed common to all investors but each investor still had to decide whether the venture was personally worthwhile in the first place. See, for instance, the investment plan recorded in one of the papyri in the Zenon Archive ${ }^{42}$ dating from ca. 256-248 BCE, where a certain lender offers Zenon three investment propositions for the exploitation of a trade ship for the period of a year, where each option contained different financial obligations with respect to crew and taxes, as well as distinct opportunities for profit. Whereas it was in the interest of all parties that the ship be utilized to make a profit, it was left to Zenon to decide his preferred course of action and the financial risk he was willing to expose himself to use the ship. ${ }^{43}$ Such instances further explain why Demosthenes accuses Lakritos of "not sharing in the danger because you put nothing on board [the ship]," as per the clause stipulating that any kind of payment is only made "upon the ship arriving safely." ${ }^{44}$ Lakritos made a personal calculation and decided that he was not prepared to invest, but still tried to illicitly make a profit without taking on the collective financial risk of the venture. Therefore, ancient traders and investors not only had a personal incentive to quantify danger, but did so using historical data to determine the risk of an investment over time.

\section{QUANTIFIABLE DEGREES OF DANGER}

Demosthenes' use of the expression "sharing in the danger" is notable for its prevalence in political and military discourse. It pertains to the

41 Oliver 2007: 40-41.

42 P. Cairo Zenon IV 59649.

43 For a detailed financial analysis of the three investment propositions, see Gachet 1990.

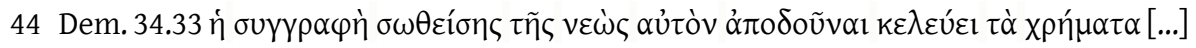

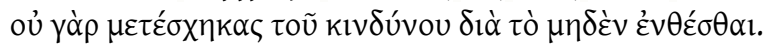


deliberative process of ancient decision-makers ${ }^{45}$ and in some cases is linked specifically to ancient efforts at quantifying danger. Polybios, for instance, describes the Roman practice of "decimation," where members of a cohort accused of cowardice were severely punished with public humiliation and even fatal beatings. Polybios considers the practice a good deterrent against cowardice because "the danger and dread of drawing the lot hang over all equally, as the outcome is uncertain; and as the public disgrace of receiving barley rations falls on all alike." ${ }^{146}$ The passage expresses what is commonly referred to as "relative perception of risk," where people are willing to accept a probability of harm up to a certain threshold, beyond which the risk is considered unacceptable - in this case $10 \%$, or one in ten. ${ }^{47}$ Such use of numerical "odds" is just one of the ways in which probabilities were expressed, and we have examples where one's risk threshold could be swayed towards taking more risks based on the increased amount of coined money promised to them. ${ }^{48}$ While we do not always have detailed pay information, we can still glimpse into how individuals quantified danger in terms of money as they weighed the potential rewards against the risk of participating in collective action.

Nor was Polybios describing "decimation" as a uniquely Roman way of approaching danger - pace Beard - as we find other instances in ancient

45 For other telling examples of personal calculations for getting involved in collective risky initiatives, see Isoc. 4.97.7 on the Spartans' decision to join the Athenians against the Persians. Also, Xen. Cyr. 5.5.20 where one of the Persian King's men is excused from sharing in the danger because he did not think it was personally safe to pursue the enemy. Conversely, the Macedonian general Parmenion was willing to gamble his life over his plan to engage the Persians by sea, saying that "he was willing even to embark himself and share in the danger," only to be dismissed by Alexander as flawed in his judgement. Arr. Anab. 1.18.6-7.

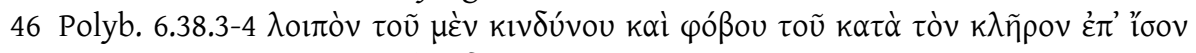

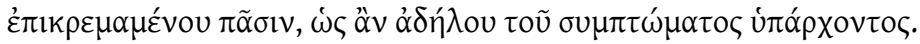

47 For more on "relative perception of risk," see Vădan 2018: 42 n. 59.

48 Alexander the Great, for instance, was able to convince his tired Macedonians to continue campaigning eastward by promising them to "make them the objects of envy to those at home, and stir up the rest of the Macedonians to readiness for shar-

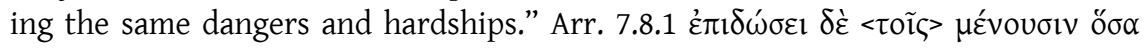

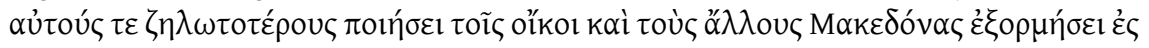

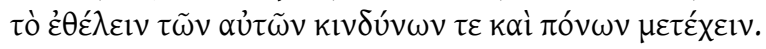


Greek literature of conveying degrees of danger in terms of numerical "odds." Diodorus Siculus tells us about the panicked call by Pancylus Paucus to his fellow Capuans to surrender to Hannibal during the Second Punic War:

He was driven out of his mind for fear of Hannibal, and he swore to his fellow citizens a peculiar oath: 'If', he said, 'there were still one chance in a hundred for the Romans, he would not go over to the Carthaginians; but since the superiority of the enemy was clear and danger was at their gates, it was necessary to yield to superiority. ${ }^{19}$

Pancylus' words are strongly rhetorical, highlighting fear as a driving force in shaping a group's risk calculations. But beyond the trope of emotions overcoming reason, the passage also suggests that the audience and, by extension, Diodorus' readers - would have understood the strength of his message because they understood its probabilistic logic. Pancylus' calculation may not have been necessarily accurate but is nevertheless expressive of the cognitive ability to assign an abstract fraction to an outcome. Similarly, Xenophon in the Anabasis also uses fractions to underline the danger that his fellow Greeks were in during their journey back to Greece. He reports that the envoy of the Persian King snidely tells them that "if you have one chance in ten thousand to save yourselves by continuing to fight against the King, I advise you not to give up your arms." ${ }^{50}$ Again, the odds given by the envoy were clearly rhetorical and were simply meant to suggest that in fact the Greeks had little chance of escape. Even so, for Spiegelhalter such basic expressions of numerical "odds" are sufficient to identify one's cognitive ability to understand and

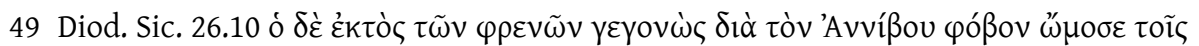

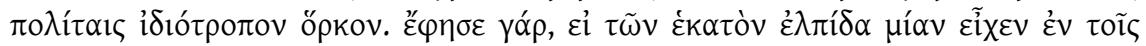

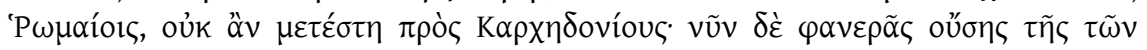

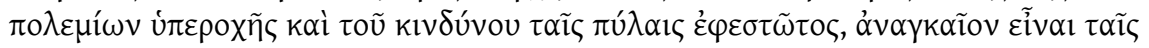

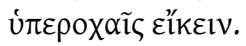

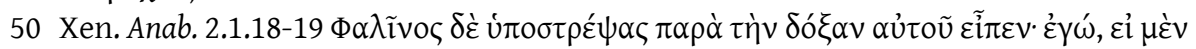

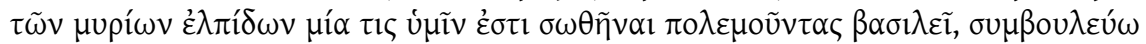

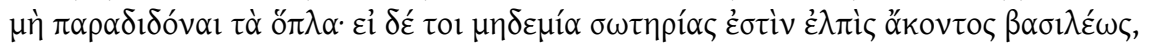

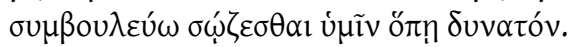


represent probabilities without the need of complex mathematical models. ${ }^{51}$

Indeed, the probabilistic thinking expressed in these examples is underlined by the use of the term $\dot{\varepsilon} \lambda \pi \hat{i}$ ' to convey chances of success. Douglas Cairns (2016) reminds us that the word does not only mean "hope," as we are sometimes wont to translate it, but can also mean "expectation" in relation to rational deliberation and endurance..$^{52}$ The term itself, therefore, signals the futurity inherent in probabilistic thinking, as protagonists formulate expectations by resorting to observation and deliberation to determine what actions are likely to have higher odds of success. It is in fact telling that early modern mathematicians also re-

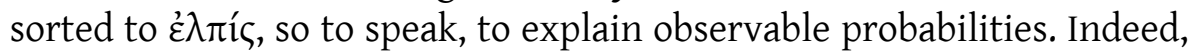
in the wake of Blaise Pascal's publication of his Usage du Triangle Arithmétique, French mathematicians began using the phrase "espérance mathématique" to refer to quantifiable probabilities; literally "mathematical hope." That is not to say that the French word "éspoir" and the Greek $\dot{\varepsilon} \lambda \pi i$ ' are causally linked, but that the probabilistic concept behind their usage is fundamentally the same, despite different technologies.

I would thus argue that the language of expectation is more useful than the metaphor of dice when accounting for probability in real sociopolitical circumstances. Crises and conflicts do not take place in a controlled environment but in a world of changing circumstances, and the language of expectation shows us how ancient decision-makers were able to communicate probabilistic variations. For instance, in one of the myriads of local conflicts that make the history of Hellenistic Anatolia a mire of confusion, the people of Pednelissos were being besieged by their neighbors the Selgians, during the summer of $218 \mathrm{BCE}$ and were about to surrender. But after receiving positive news that the Seleukid general Achaios would send the help that they had earlier asked for, "The Pednelissans undertook the siege boldly, relying on their hopes ( $\dot{\varepsilon} \lambda \pi i$ ol) of salvation, and Achaios, appointing Garsyeris to command the expedition, dispatched him with six thousand foot and five hundred horse to 
the Pednelissans' assistance." ${ }^{53}$ The timely promise of assistance thus led the defenders to alter their risk calculations, feeling confident that their chances of success were increased, which in turn induced them to persevere under siege. In the absence of game theoretical scenarios and equations, the Pednelissans speak to the cognitive ability of Hellenistic communities to articulate probabilities in culturally specific terms. The difference between ancient and modern probability, therefore, appears as one of form rather than substance.

\section{QUANTIFYING WAR AND PEACE}

As our previous examples show, "odds" of success were often correlated to concrete numbers. Since war was the most dangerous game to play, ancient military commanders were understandably concerned with determining their "odds" of victory. They did so in part by tallying up and comparing the number and composition of armies and resources. ${ }^{54}$ Indeed, ancient historians offer many examples of commanders deciding on a course of action based on their (in)sufficient forces compared to

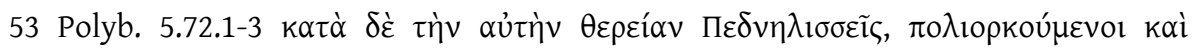

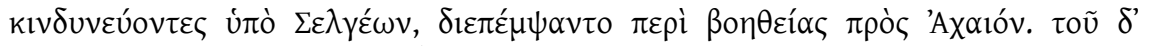

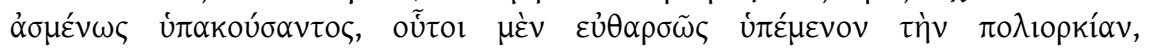

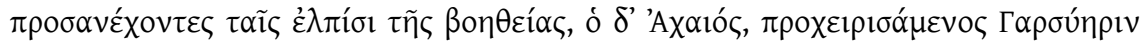

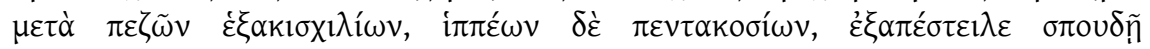

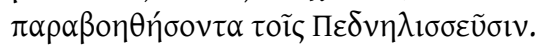

54 For instance, the Punic Wars are described by Polybios as an arms race, where both sides initially thought that the contest was even, which in turn spurred each of them to acquire more ships and manpower. Polyb. 1.25.5. We are also told that, desperate to increase their odds of victory, the Romans "were so alarmed and anxious as to the future that they decided to bring into action not four legions but eight." See Polyb.

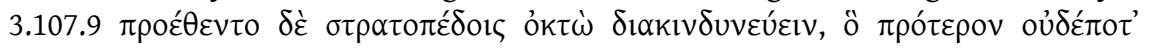

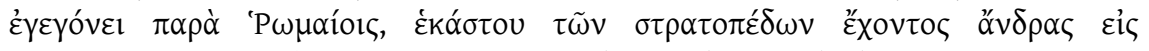

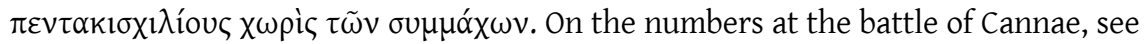
also Polyb. 3.117. See also Polyb. 1.53.10 on the Carthaginians who considered themselves not strong enough to engage the Romans on account of their inferior numbers. 
those of the enemy ${ }^{55}$ This has led me (Vădan 2018) to argue that Hellenistic decision-makers understood the concept of risk as a deliberative ex-

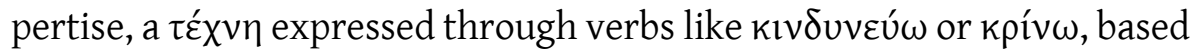
on one's experience, knowledge, and sagacity. ${ }^{56}$ In turn, Roel Konijnendijk (2020) has recently shown that "Classical Greeks would not have accepted the gamble of battle in the open without careful deliberation." ${ }^{57}$ This attitude, in turn, explains why Xenophon and Aristotle

55 Xen. Anab. 3.4.14, 7.1.20; Polyb. 1.53.10, 1.25.5, Fr. 6 (Suda $\alpha$ 1312). In this light, the wars of the Athenians and Macedonians against the Persian Empire are the exceptions that strengthen the rule, so to speak, where local communities and potential allies "had little respect for the small numbers of the [former] but were much impressed with the great size of the [latter], abandoned Alexander and came over to Dareios. They brought the Persians food and other materials with great goodwill, and based on their own decision they foretold the victory of the barbarians." Diod.

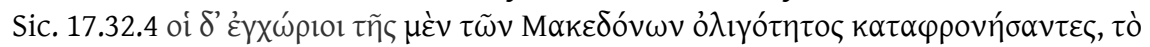

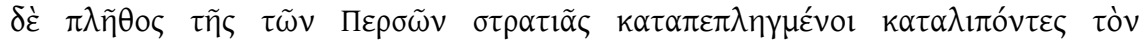

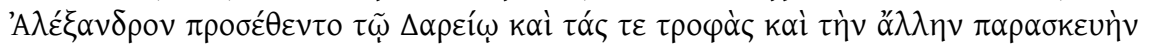

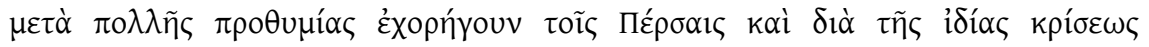

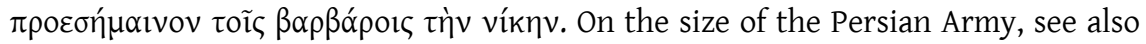
Hdt. 7.184-87 and later during the campaign of Alexander Arr. Anab. 3.8.3-6. At the same time, others sought to make their army seem larger so as to deter an enemy attack or to psychologically overwhelm the opponent to surrender, as in the case of the siege of Rhodes where Demetrios the Besieger made sure that "the whole space between the island and the opposite shore was seen to be filled with his vessels, which brought great fear and panic to those who were watching from the city." Diod

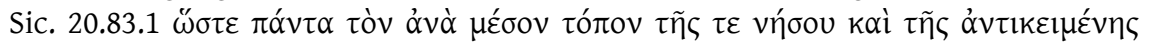

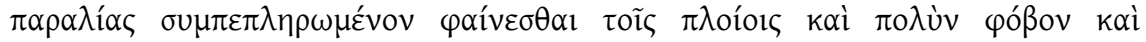

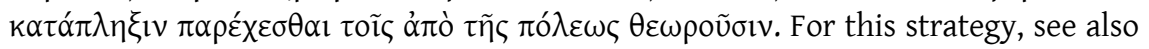
Xen. 3.4.13 and Plut. Eum. 15. We can think of such prognostications ( $\pi \rho \circ \sigma \eta \mu \alpha \sigma i \alpha l)$ as the "odds" calculated with concrete numbers that in turn informed the decisions of the many smaller factions caught between the two main antagonists.

56 Polybios believed that one's deliberative expertise could lead one to make seemingly

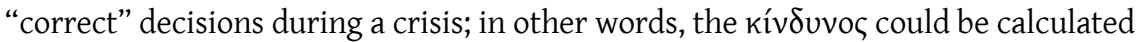
and handled in any situation. Vădan 2018: 27-40.

57 Battle was considered a risk that was not always worth taking if necessity did not demand it, while "senseless" leaders were censured for "playing dice with the whole city at stake." Xen. Hell. Oxy. 1.2; Diod. Sic. 13.65.2. By contrast, someone like Phrynichos was praised by Thucydides for not "running a risk senselessly," but calculated carefully, weighing the potential rewards versus dangers 8.27.2-3 (Konijnendijk 2020: 183-84). 
consider it imperative for a leader to know the resources and expenses of the state, its diplomatic standing, and the state's military capability to make correct estimations. In his Memorabilia, for instance, Xenophon offers an enlightening conversation between Sokrates and a young, ignorant Glaukon:

S. In order to advise about whom to fight, it is necessary to know the city's strength and the enemy's so that if the city is stronger one may recommend going to war, but if weaker, being cautious.

G. You are right.

S. First then, tell us the naval and military strength of our city, and then that of her enemies.

G. No, of course I can't tell you it out of my head.

S. Well, if you have made notes, fetch them, for I would greatly like to hear this.

G. But, I tell you, I haven't made any notes either.

S. Then we will postpone offering advice about war too for the present. $^{58}$

The dialogue highlights the reliance on the numbers of troops and resources to quantify success in a possible conflict and shape foreign policy accordingly. ${ }^{59}$ The detail that such information would have also been available in written form ( $ү \varepsilon ́ \gamma \rho \alpha \pi \tau \alpha l)$ suggests that a seasoned

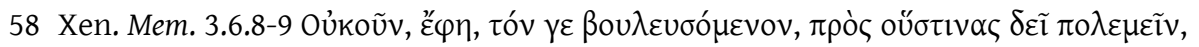

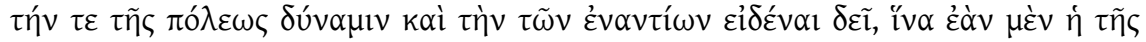

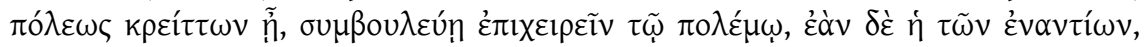

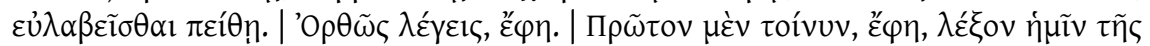

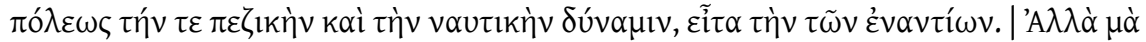

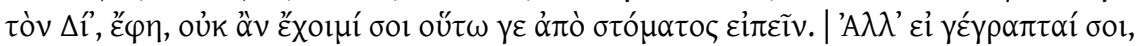

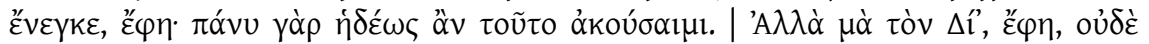

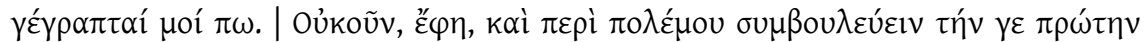
$\varepsilon \dot{\pi} 1 \sigma \chi \eta \dot{\sigma o} \mu \varepsilon v$. See also the extensive education young Alexander received from some of the finest tutors that his father could hire to get him ready to rule. Plut. Alex. 5.

59 We may add as a further example Perikles' detailed account of Attic geography and Athenian naval forces to convince his fellow Athenians to persevere in their conflict with the Spartans and their allies: "to these Perikles added other arguments, such as he was accustomed to do, as proof of their superiority in war." Thuc. 2.13.7-9 $\varepsilon \bar{\varepsilon} \lambda \varepsilon \varepsilon$

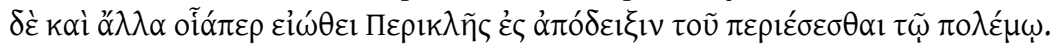


commander like Xenophon would have made balance sheets comparing the two forces in an attempt to determine what military action to take. And in fact, he gives us such a balance sheet in his Anabasis, in a speech to his fellow Greeks that includes an overview of the strengths and weaknesses of the two opposing forces:

If anyone of you is despondent because we are without horsemen while the enemy have plenty at hand, let him reflect that your ten thousand horsemen are nothing more than ten thousand men; [...] moreover, we are on a far surer foundation than your horsemen: they are hanging on their horses' backs, afraid not only of us, but also of falling off..$^{60}$

Xenophon goes on to tell his men that they should not worry either about the terrain or about the lack of guides. His address is obviously rhetorical to the point of absurdity insofar as having fewer men in a foreign country is touted as a benefit; logic is turned on its head. But it reveals two important points pertaining to ancient probability. On the one hand, Xenophon needed to address his men's fears because according to their own calculations their inferior numbers did decrease their chances of returning home to Greece. On the other hand, Xenophon's men also noted that not all troops were alike, and that horsemen had different uses and benefits in particular circumstances, thus demonstrating combinatorial thinking where not only the number but also the type of troops are used to calculate odds of victory. ${ }^{61}$

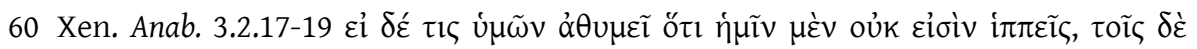

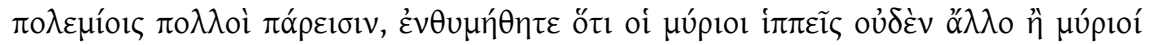

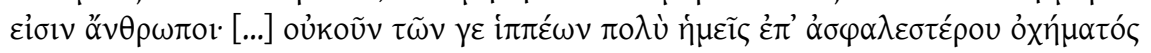

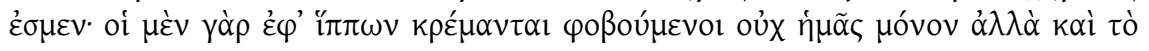
$\kappa \propto \tau \alpha \pi \varepsilon \sigma \varepsilon \tilde{\mathrm{i}} v$.

61 See also Polybios' verdict on the battle of Cannae (3.117.4-6) where about seventy thousand Romans died: "both on this occasion and on former ones their numerous cavalry had contributed to the victory of the Carthaginians, and it demonstrated to posterity that in times of war it is better to give battle with half as many infantry as the enemy and an overwhelming force of cavalry than to be in all respects his equal."

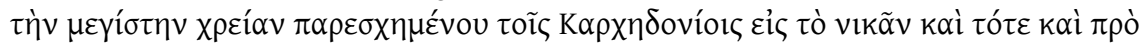

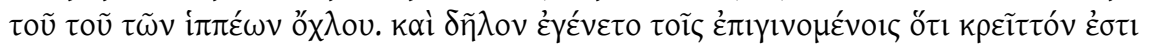


To be sure, sheer numbers were certainly not the only criterion for deciding a battle. One's talents as a general, the soldiers' experience, their mental state, the character of the battleground, etc., all could prove decisive. But for Aristotle numbers were nevertheless a good indicator that allowed one to think probabilistically about the future and improve their odds of success. One long passage in the Art of Rhetoric is worth quoting:

[A leader] should know all the expenses of the state, that if superfluous, it may be removed, or if too great, may be curtailed [...] of these matters it is not possible to acquire a general view from individual experience alone, but in view of advising about them it is further necessary to be well informed about what has been discovered among others. In regard to war and peace, the rhetor should be acquainted with the power of the state, how great it is already and how great it may possibly become, of what kind it is already and what additions may possibly be made to it; [...] These matters he should be acquainted with, not only as far as his own state is concerned but also in reference to neighboring states, and particularly those with whom there is a likelihood of war, so toward the stronger a pacific attitude may be maintained, and in regard to the weaker, the decision as to making war on them may be left to his own state. Again, he should know whether their forces are like or unlike his own, for herein also advantage or disadvantage may lie. ${ }^{62}$

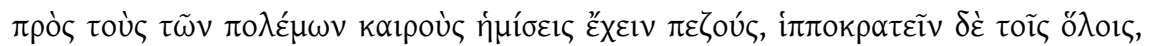

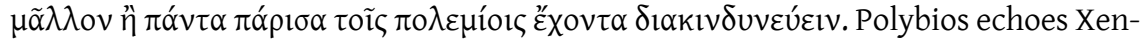
ophon by highlighting how different configurations of troops can generate different results that can be quantified loosely in terms of casualties.

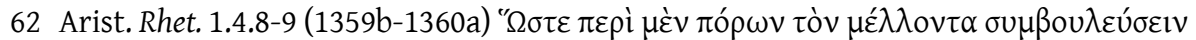

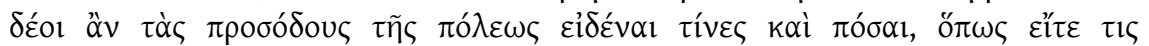

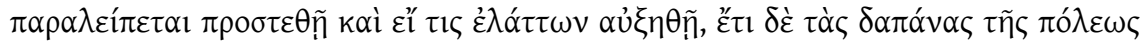

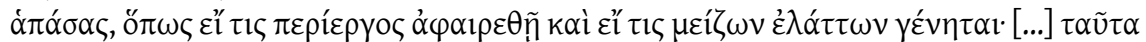

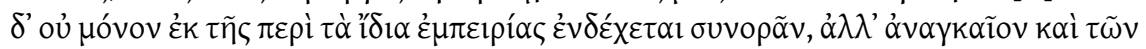

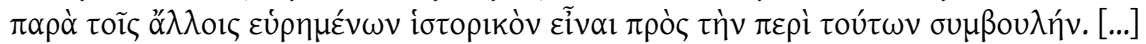

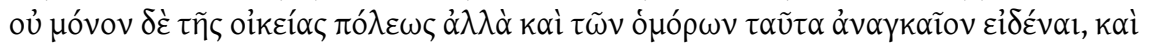

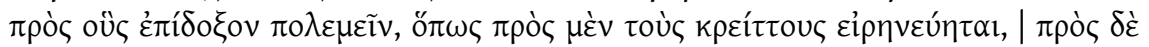


While echoing Xenophon's emphasis on the size and character of an army and its resources, Aristotle is particularly concerned with how this information could be manipulated to increase the calculable odds of success and help make decisions about the future. Notice, for instance, the correlation between addition and possible outcome as expressed by

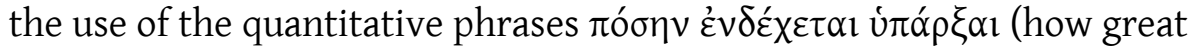

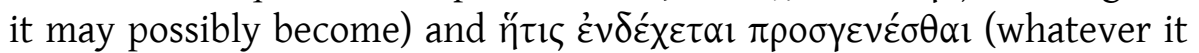
may be possible to add) relative not only to one's own power but also to

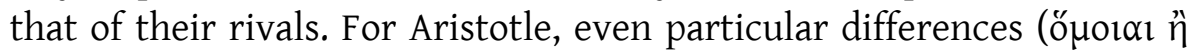
óvó $\mu$ or $\alpha$ l) could be quantified, as shown through his use of the infinitives

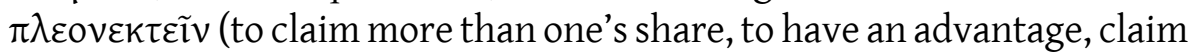
a larger share) and $\dot{\varepsilon} \lambda \alpha \tau \tau o \tilde{v} \sigma \theta \alpha \iota$ (make smaller, diminish, reduce in amount). The moral meaning of the verbs expressing greediness and degradation comes from their more technical quantitative meaning expressing addition and reduction. In this particular case the infinitives signal advantage and disadvantage insofar as they increase or diminish one's odds of success.

Both Xenophon and Aristotle, then, prescribe how leaders armed with detailed information could quantify the (un)certainty of war and peace and plan their future steps accordingly. A case in point is Demetrios the Besieger's decision,

though short of money, to double his army by new levies. And when some of his friends in surprise asked him, how he expected to pay them, when he found it difficult to support a smaller force; "the more powerful we are", he replied, "the weaker we shall find our enemies; and the more easily make ourselves masters of their country. From thence tribute and free gifts will come in, that will soon fill our coffers." ${ }^{\prime 3}$

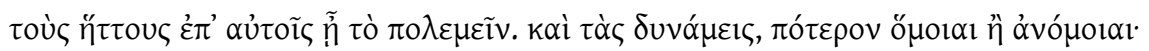

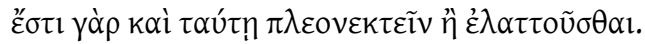

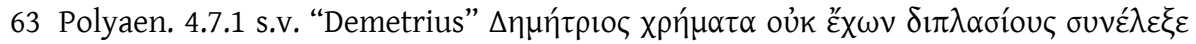

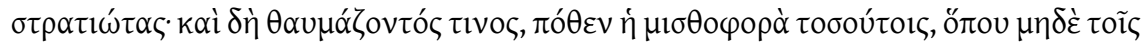

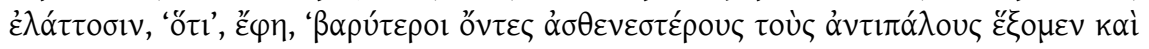


The passage highlights the fascinating discrepancy in perception between Demetrios and his friends. Whereas the latter are solely focused on their present circumstances, Demetrios looks to the future by using probabilistic thinking to determine the best course of action. In other words, his financial gambling is in fact an investment into making his chances of possible victory stronger ( $\beta \alpha \rho u ́ \tau \varepsilon \rho o l)$ relative to his soon-to-

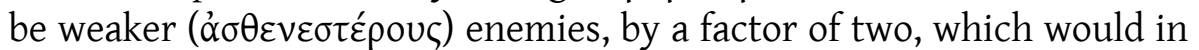
turn bring him a significant return on that investment. Demetrios' initiative, like our earlier examples, therefore, reveal that for ancient decision-makers statistical thinking became what psychologist Gerd Gigerenzer calls "a habit of mind." ${ }^{4}$ They had the incentive and the inclination to convert various quantities into a single abstract value of uncertainty to make informed decisions about present and potential dangers.

\section{QUALITATIVE PROBABILITY}

Numbers are not the only means to express probability. Risk analysts Baruch Fischhoff and John Kadvany (2011) explain why estimative language plays a crucial role in communicating uncertainty in important socio-political contexts: because analytical judgements are inherently not certain, decision-makers use probabilistic language to reflect the estimates of the likelihood of developments or events. ${ }^{65}$ Such language appears prominently in ancient philosophy and forensic oratory, though its use by ancient historians regarding practical decision-making has not received extensive attention. In fact, historians and local leaders use terms like عikós to express the probability of an outcome during the

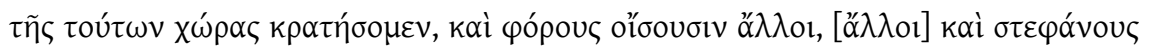

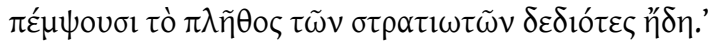

64 Gigerenzer 2002: 245.

65 Fischhoff \& Kadvany 2011: 126-27. 
decision-making process. ${ }^{66}$ In this regard, Thucydides's use of the term during the speech of the Korinthians on the eve of the Peloponnesian War is instructive: they explain to their Peloponnesian allies that "For many reasons it is likely (घikò) for us to prevail: firstly, because we are superior in numbers and military experience, then because we follow all orders ... so if we win a single victory at sea, [the Athenians] are most

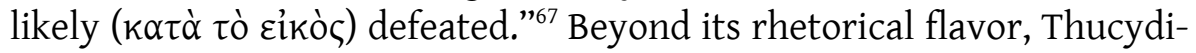
des uses this passage to point out that likelihood of success is not merely a matter of guesswork but the product of calculation that took into account perceived experience, general inclination, circumstances and, of course, the sheer number of troops, ships and resources.

Decision theorists interpret such estimations as expressions of "qualitative probability", which represents "a theory of probability based on qualitative ordering of events in terms of their likelihood of occurrence. ${ }^{168}$ In times of crisis, ancient leaders and communities ultimately had to choose between a set of difficult options, each with their own dangers and consequences, that could often be reduced to a binary response

66 For detailed discussions and examples of argumentation through likelihood (zikóc, Eỉót $\alpha$ ) in forensic oratory, see the contributions by Michael Gagarin and Craig Cooper in A Companion to Greek Oratory (Gagarin 2007: 27-36 and Cooper 203-19, respectively). Consider the famous hypothetical example of whether a weak man is (un)likely to be charged with assaulting a strong man (and vice-versa) (Arist. Rhet. 2.24.11). On the one hand, the weaker man would have smaller chances of success against a stronger man, which would make him wary of committing such a crime. On the other hand, given such general expectations of success, the stronger man would also be unlikely to assault a weaker man because everyone would think him to be the likely suspect; Gagarin calls it "a reverse argument from likelihood." Gagarin 2007: 32. For the first uses of the language of probability in Greek literature, starting with the Homeric Hymn to Hermes, see Kennedy 1995:11-29. On the extensive use of zikó by Attic rhetoricians to suggest likelihood of guilt based on character rather than forensic evidence, see further Kennedy 1995: 64-80.

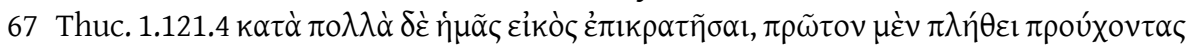

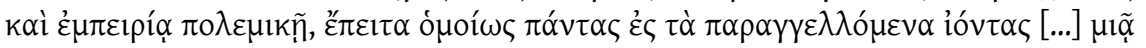

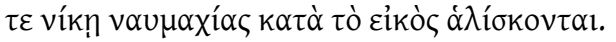

68 Narens 2007: 29. Note also Meusnier's (2008: 108) observations on the assumed discontinuity in recent scholarship between qualitative and quantitative approaches to probability, which leads to the perceived "sudden" appearance of probability theory after its "discovery" by Pascal, Fermat, and Huygens. 
- "yes" or "no", action or inaction, attack or defend, etc. Preferable courses of action could also be expressed through comparative adjectives. As with zikós, adjectives add "gradations" of risk to these kinds of binary contrasts. Diodorus Siculus, for instance, portrays the convoluted history of the Successor Wars that erupted immediately after the death of Alexander the Great, through a detailed description of the thought process of an otherwise unremarkable commander by the name of Peukestes. This Peukestes was one of the many Macedonian leaders who had been prominent at Alexander's court, and who now sought to carve the dead King's empire among themselves. When he was asked by several others to send help against an increasingly belligerent and powerful Antigonos Monophthalmos, who wanted to take it all for himself, Diodorus tells us that:

At first [Peukestes] paid no heed to them [...] since he still bore a grudge for not receiving a generalship; but later, reasoning with himself, he conceded that should Antigonos be victorious, the result would be that he himself would lose his satrapy and thus also risked

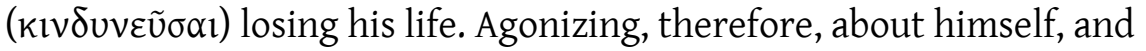
thinking that he would be more likely ( $\mu \tilde{\alpha} \lambda \lambda$ ov) to gain the command if he had as many soldiers as possible, he brought forth ten thousand archers, as they requested. ${ }^{69}$

The passage's many verbs of pondering draw our attention on Peukestes' step-by-step thought process in a series of "if... then..." clauses, as we are privy to how he determines what his options are, along with their probable consequences. In this context, the comparative $\mu \tilde{\alpha} \lambda \lambda$ ov points to Peukestes' deductive logic based on what scenario he deems more likely to occur.

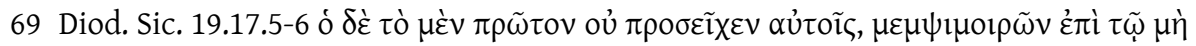

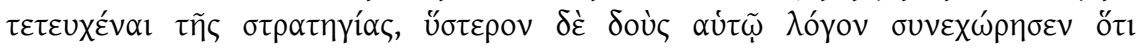

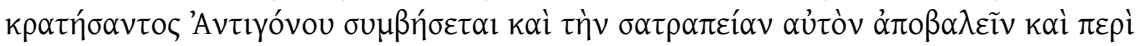

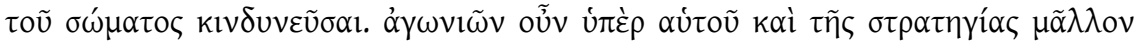

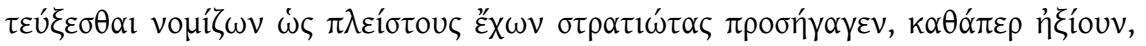

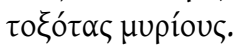


However, the full force of Diodorus' passage would be lost if we simply agreed that we are dealing with a "rational" actor who eventually makes the objectively "correct" choice. His account is not merely retrospective but captures the internal doubt and discomfort of Peukestes in having to make a difficult choice. We see the commander literally agonizing $(\dot{\alpha} \gamma \omega v i \tilde{\omega} v)$ over the preferable course of action. Having to help others at the expense of Antigonos, even though likely more beneficial, is not a particularly comforting thought considering the agonistic character of Macedonian politics. Peukestes settles on a solution by conjuring up different potential futures, mirroring Aristotelian decision-trees, each with their own series of steps and possible consequences that take into account military capabilities, geo-political circumstances, but also the personal character of his rivals; an otherwise notoriously difficult factor to quantify using formal statistical analysis.

Expressions of preference might strike some as not indicative of "proper" probabilistic thinking. But Spiegelhalter reminds us that whatever probabilistic model we adopt - be it classical or frequentist - it remains true that "probabilities are constructed based on existing knowledge, and are therefore contingent,"70 an admittedly controversial statement that informs Bruno de Finetti's famous quote at the beginning of this paper, "probability does not exist." Spiegelhalter takes this statement to mean that "probabilities are not states of the world [...], but depend on the relationship between the 'object' of the probability assessment, and the 'subject' who is doing the assessing." 71 The relational character of probability thus allows us some insight into how decision-makers can incorporate even subjective elements such as perceptions, experience, and emotions into their calculations by assigning to them qualitative values and priorities.

Indeed, the most generative strategy that ancient decision-makers used to assess the future was the conceptual linking of the past with the present through perceived historical precedents. Particularly in warfare, a record of past encounters was touted as indicative of likely outcomes. ${ }^{72}$

70 Spiegelhalter 2011: 20.

71 Spiegelhalter 2011: 20-21.

72 In the Latin context, we have examples from Caesar and Tacitus that express probability through precedent. Specifically, in Caes. BCiv. 3.73 Caesar gives a speech before 
Returning to The Art of Rhetoric, Aristotle further qualifies the reliability of numbers to calculate odds of success by relying on the historical dimension to add perspective to the assigned value of state power. He states succinctly that "with reference to these matters he must also have examined the results not only of the wars waged by his own state, but also of those waged by others; for similar results naturally arise from similar causes." ${ }^{73}$ Aristotle understood that quantitative and qualitative probabilities can be brought together by decision-makers to generate helpful statistics informing the correlation between past outcomes and present circumstances. Polybios attributes such a statistical mindset to the Roman general's assessment of the Macedonian enemy before the battle of Kynoskephalai in 196 BCE, which would humble the Macedonian kingdom and establish a Roman presence in subsequent Greek affairs. Facing the professional army of Philip V, the Roman general Titus Quinctius Flamininus delivered a short speech to his troops in which he asked rhetorically:

Are these not the same Macedonians whom, when they held that desperately difficult position in Epirus, you compelled by your valor to throw away their shields and flee, never stopping until they got home to Macedonia? What reason, then, have you got to be timid now when you are about to battle the same men on equal terms? Why not foresee the past instead of dreading an opposite outcome, and dare? So, my

his troops after the battle of Dyrrhachium, urging them "not to be discouraged, or give way to consternation, upon what had lately happened, but oppose their many successful engagements to one slight and inconsiderable check" (ne ea quae accidissent graviter ferrent, neve his rebus terrerentur, multisque secundis proeliis unum adversum et id mediocre opponerent). He was careful to point out that their single loss was due to their small numbers, as well as unprecedented circumstances and - alas - unfavorable fortune, which was bound to turn in their favor. Similarly, in Tac. Ann. 1.61-62. It is also worth noting Caecina's expertise; he was on his fortieth campaign. His experience of success and peril had made him fearless: Tac. Ann. 1.64.6 quadragesimum id stipendium Caecina parendi aut imperitandi habebat, secundarum ambiguarumque rerum sciens eoque interritus.

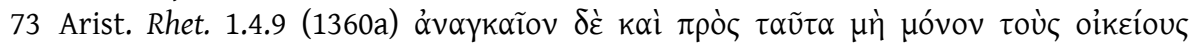

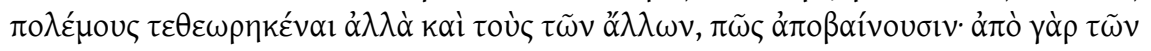

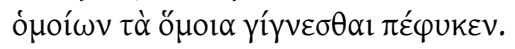


men, encouraging each other, dash on to the fray and put forth all your strength. For with the gods willing, I feel sure that this battle will end like the earlier dangers. ${ }^{74}$

Polybios uses the speech to bring attention to the morale boost that past victories gave the troops, a practice that many generals routinely used. But Polybios also touches on the deliberative process that informed the soldiers' confidence. In other words, precedent did not cause an automatic reaction, but was rationally consulted. Flamininus stimulates his men's observational skills to get them to realize that they are fighting the same enemy under comparable conditions, appealing to the image of the enemy's previous cowardice to drive home his point. He then encourages them to maintain their determination - based on past outcomes, there is no real reason for them to expect a different result. The interplay between past and future is elegantly highlighted by the call "to foresee the past." In using this phrase, Polybios stakes a claim that the Romans' stance was not merely a matter of courage and honor, but was the result of an informed decision based on previous encounters with similar outcomes, which in turn helped Flamininus calculate the projected risk of the battle.

Xenophon makes a similar pitch to his Greek companions at the outset of the Anabasis. He claims that he entertained - the gods willing many and beautiful hopes of salvation, ${ }^{75}$ not only because they themselves were righteous pious men fighting against perjurers, bound to incur the wrath of gods. He also relied on the record of the Greeks in their past encounters with the Persians, starting from the Persian Wars and

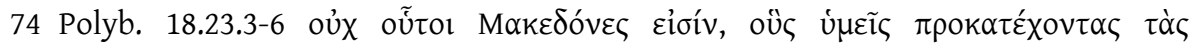

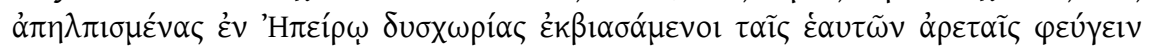

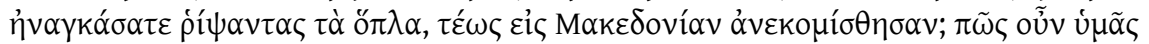

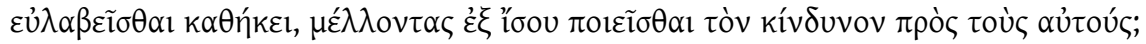

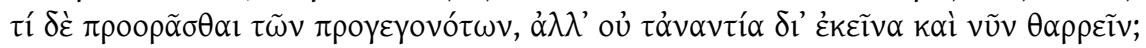

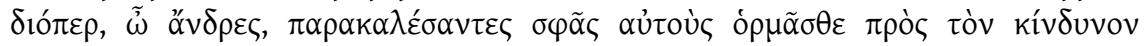

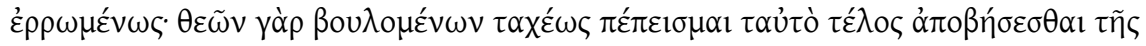

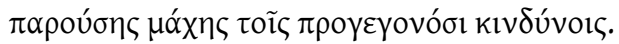

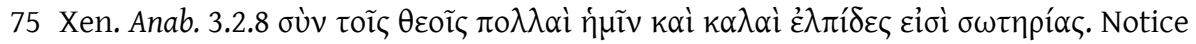
again the emphasis on "beautiful hopes" to suggest good chance of success. (See Ch. 1). 
on to their most recent encounters as part of their support in Cyrus' bid to the throne of Persia, when "you stood in formation against the descendants of those [ancient Persians], who far outnumbered you, and were victorious with [the aid of] the gods [...] proving to be brave men."76

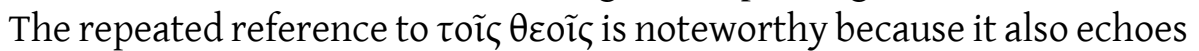

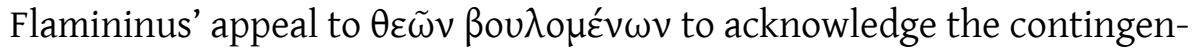
cies of war and the inherent dangers that lie therein. ${ }^{77}$ But more importantly, Xenophon's mention of a tradition of victory against the Persians served not only to spur morale, but also to suggest that past encounters were instructive on how to deal with the same enemy:

It is now more appropriate to be more daring to go against the enemy, for in the past you were ignorant about them, considering their host numberless, and nevertheless you dared to go against them with ancestral resolution. For now, when you have already had proof that they are unwilling to receive your charge even though they are many times more numerous, what reason is there for you to fear them $?^{78}$

Xenophon's speech is a masterstroke in mass persuasion that discloses the great lengths to which commanders would go to equate present conditions to successful past enterprises, particularly in unfavorable situations. Yet despite the rhetorical character, its probabilistic logic persists because, as in Polybios' example, it is grounded on a cumulative gathering of information. Starting from a point in time when the Greeks were ór $\pi \varepsilon 1 \rho \circ$ (inexperienced, unused to, unacquainted with) vis-à-vis the enemy's military capabilities, their experiences gradually increase their

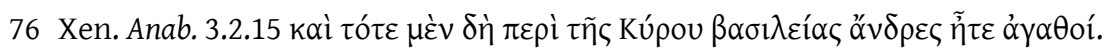

77 I will explore this topic in a forthcoming article on Polybios' conceptualization of contingency planning.

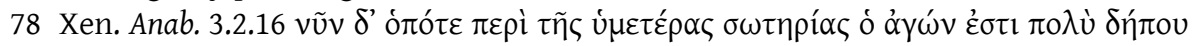

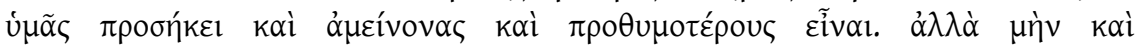

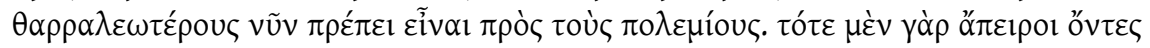

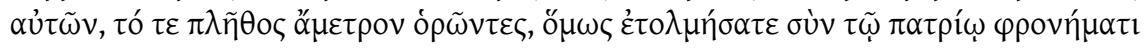

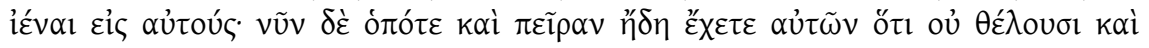

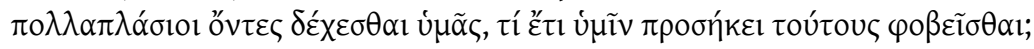


knowledge of their enemy, as highlighted by the passage's many comparative adjectives. In such circumstances, a string of past successes is suggestive, at least in theory, of future victories. ${ }^{79}$

History, as such, was not merely didactic in a moral sense, but was thought to contain practical knowledge that could be consulted to determine one's odds of success, where numbers and attitudes were placed in a historical context to be consulted during ostensibly similar circumstances. This tried-and-tested method eventually developed into a standardized form of education that culminated in the production of technical manuals. Xenophon's On Horsemanship, Aeneas Tacticus' On the defense of Fortified Positions, Onasander's On Strategy, and Polybios' now-lost On Tactics, are replete with precedents in various situations that were meant to inform a decision-maker's choices in matters of war and local administration. Beside oracular consultation and divination, then, ancient thinkers also prescribed a probabilistic system of knowledge that rendered the future calculable and thus more imaginable.

\section{PRECEDENT VERSUS ADAPTATION}

Similarity is nevertheless not sameness, especially when statistics are involved. In fact, the logic that past successes necessarily translate into further victories is a probabilistic mistake, the so-called "hot hand fallacy." Especially in warfare, new encounters are independent events, and their odds of success will not depend strictly on the past; new conditions, information, and many other factors, can influence the outcome. Ancient historians were well aware of this logical fallacy and sought to render it intelligible for their contemporaries. Xenophon, for instance, expressed his support for the Common Peace of 371 BCE by equating the irredentism of Athens and Sparta to the compulsive behavior of gamblers and athletes:

79 A similar calculation was made by the Melians after having resisted the Athenians earlier in the war (Thuc. 3.91). But in the Melian dialogue Thucydides chooses not to emphasize this point and instead make an argument about the pitfalls of relying on hollow hope instead of rational calculation (Thuc. 5.116). 
I for my part do not commend those men who, when they have become competitors in the games and have already been victorious many times and enjoy fame, love winning so much that they do not stop until they are defeated and cease their training. Nor, on the other hand, do I commend those dicers who, if they win one success, throw

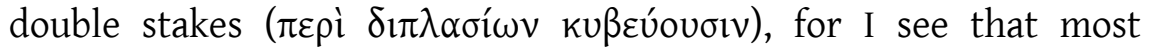

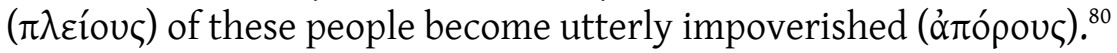

This bullish attitude is well-known among psychologists and game theorists. ${ }^{81}$ They agree with Xenophon that, while a lucky few might succeed, the great majority of those who adopt it are statistically bound to fail and become árópous, as Xenophon's use of the comparative adjective $\pi \lambda$ cíouৎ suggests. One must instead hedge their bets and be aware of circumstances and trends, and not "engage in a contest of such a sort that we either win all or lose all"; 82 blind faith in past outcomes is not enough.

Xenophon is thus drawing attention to the essential skills of adaptation and improvement that decision-makers must possess. Otherwise, they will suffer the fate of the Spartans at the hands of Kallias son of Hipponikos just outside of Korinth in 390 BCE during the so-called Korinthian War. Xenophon recounts how, upon splitting up their forces and returning to Lechaion, "[the Spartans] were by no means unaware that there were many peltasts and many hoplites in Korinth, but on account of their previous successes they contemptuously thought that no one would attack them." Their enemies, on the other hand, "when they saw that [the Spartans] were few in number, but also unaccompanied by either peltasts or cavalry, thought that it was safe to attack them with their

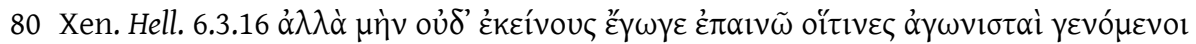

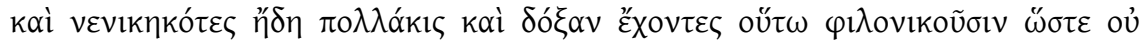

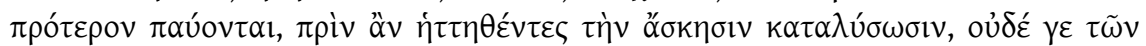

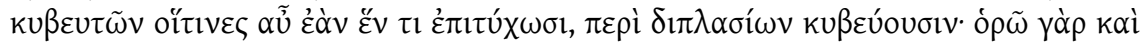

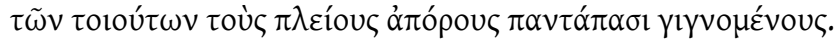

81 Konnikova 2020a; 2020b.

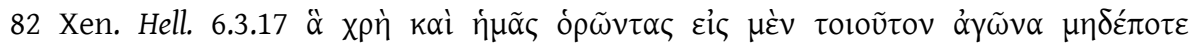

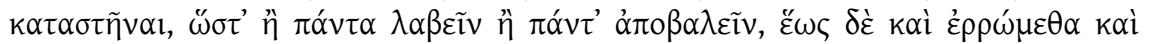

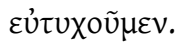


force of peltasts." ${ }^{83}$ Xenophon contrasts Kallias' observation ( $\kappa \alpha \theta \circ \rho \tilde{\omega} v$ $\tau \varepsilon \varsigma$ ) followed by his estimation ('่vó $\mu 1 \sigma \alpha v$ ) of the changed circumstances

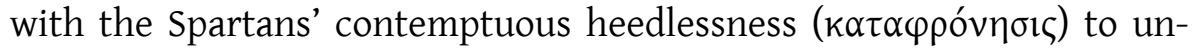
derline the importance of continually being mindful of changes and constantly striving to improve one's condition, especially in high stakes matters.

The example further indicates that in such real-time scenarios, like politics or sports, rivals learn from each other with every encounter, making the next clash all the more interesting because its outcome is not only determined by past results, but also by the changes that each side adopts in trying to predict the possible actions of the adversary; a really good team, for instance, is able to predict the opposition's predictions, as it were. The rise and rule of Rome offers a fascinating historical case study because Greek historians tend to explain it precisely as the result of the Romans' ability to learn from past failures and improve going forward. Their talent is apparent when they manage to overcome their more established Carthaginian rivals in the naval arena during the First Punic War. The war was rooted in the growing influence of the two Republics in the Western Mediterranean which made an eventual confrontation between the two powers virtually unavoidable. Polybios is particularly interested in this conflict and starts his Histories with it, because he interprets it as the first clear proof of the Romans' future greatness. He repeatedly mentions the Romans' traditional naval (in)experience, but adds that "When they once conceived of the project, they took it in hand so boldly, that before gaining any experience in the matter they at once engaged the Carthaginians, whose hegemony of the sea had been undisputed for generations." ${ }^{84}$ The Romans, according to Polybios, knew that the key to eventual victory against the Carthaginians - or against

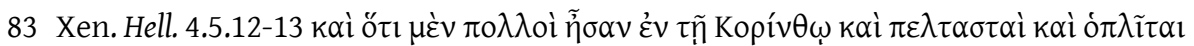

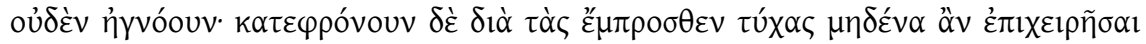

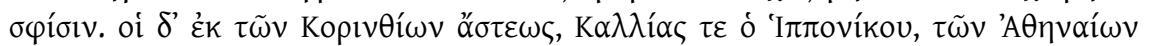

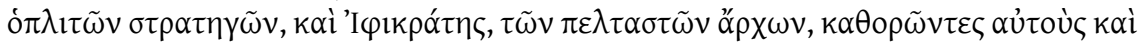

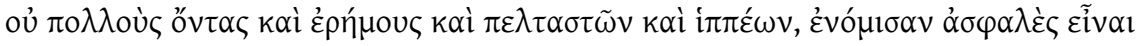

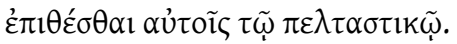

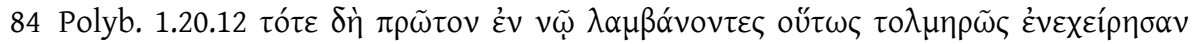

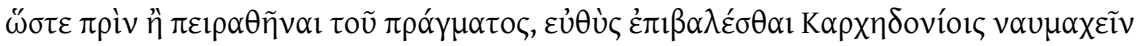

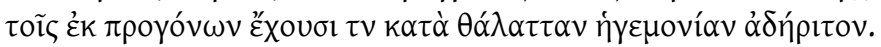


any enemy, in fact - was beating them at their own game, which meant being prepared to accept many losses for the sake of improvement. Looking at the record between the two fleets, people would understandably be tempted to bet on the Carthaginians, based on past results. But those gamblers would be sorely disappointed as the Romans were eventually able to routinely defeat their Punic adversary.

This tension between precedent and improvement also governs Diodorus Siculus' account of the interaction between the Carthaginian and Roman envoys on the eve of the First Punic War. On their part, the Carthaginians appeal to precedent to suggest that they are bound to win any future encounter, "[as] they wondered how the Romans dared to cross into Sicily while the Carthaginians were the masters of the sea, for it was obvious to all that, should they not protect their friendship, they would no longer dare to even wash their hands in the sea." ${ }^{85}$ By referring to their own record of success as $\varphi \alpha v \varepsilon \rho o \dot{v} \pi \tilde{\alpha} \sigma \mathrm{lv}$, the Carthaginians warned the Romans against trying to threaten their naval prowess. The Romans, by contrast, ostensibly emphasized the importance of accumulated experience to improve where they had failed in the past. Thus, while not denying the Carthaginians' present naval power, they issued a warning of their own, that the Carthaginians' prominence would ultimately prove their own undoing: "for the Romans have always turned out to be pupils stronger than their teachers." ${ }^{6}$

These passages reveal an ancient understanding of the probabilistic feature regarding incremental success currently known among economists as a "power law," representing a relationship between two quantities, like the chances of victory going into battle, where changes in one quantity lead to a proportional relative change in another. Whereas in a game of dice where statistical data is collected from dice throws with the same aleatory chance, this incremental model suggests that one result say one battle between the Romans and the Carthaginians - will then pro-

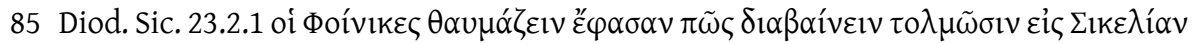

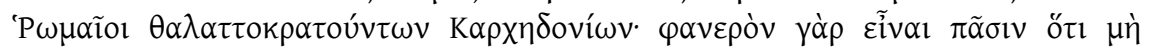

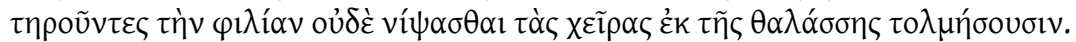

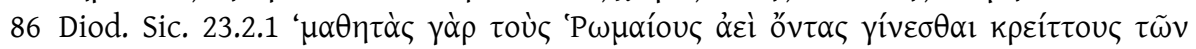
$\delta 1 \delta \alpha \sigma \kappa \alpha ́ \lambda \omega v . '$ 
portionally impact the chances of the Romans during their next encounter, and so on. Sergio Da Silva, Raul Matsushita, and Eliza Silveira (2013) have looked at sports and war and have found that in both circumstances when antagonists compete, "there emerges stasis, as each adaptation by one in countered by an adaptation by the other. The co-evolution between the antagonistic sides eventually reaches equilibrium and a fairly regular power law takes place." ${ }^{87}$ Eventually, since perfect counter-adaptation is unfeasible, one side is bound to gain the upper hand, which in turn furthers its chances of success with successive repetitions; provided, of course, that it remains focused on adapting to circumstances and learning how to do things better. ${ }^{88}$ We find the same phenomenon in the case of Roman success, who became increasingly more difficult to defeat in any single subsequent encounter because they kept learning, adapting, and improving. By the Third Punic War, when Carthage was razed to the ground, the Romans only needed marginal refinement against their massively disadvantaged enemy.

Importantly, the Romans were not exceptional in this regard. Historians use the same logic of adaptation and refinement to explain the rise and fall of other erstwhile powers like Athens, Sparta, and Thebes. Xenophon explains Athens' long-term naval superiority through the voice of Prokles the Phliasian who observes that

you already possess many triremes and it is your naval tradition

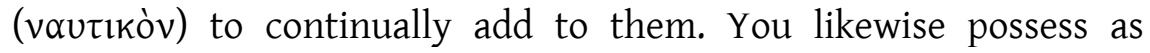
peculiarly your own all the arts and crafts which have to do with ships. Again, you are far superior to other men in experience of nautical affairs, for most of you get your livelihood from the sea. [... As a result,] you have engaged in very many and very great combats by sea, you have met with an exceedingly small number of misfortunes and have achieved an exceedingly large number of successes. Therefore, it is likely that the allies would like best to share in such danger if they were under your leadership. ${ }^{89}$

87 Da Silva, Matsushita \& Silveira 2013: 5382-83.

88 Da Silva, Matsushita \& Silveira 2013: 5384-85.

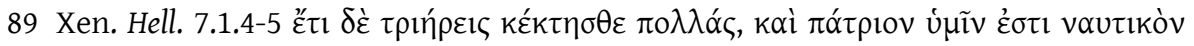

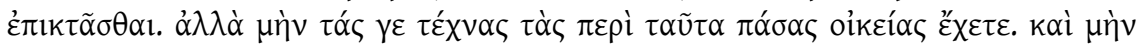




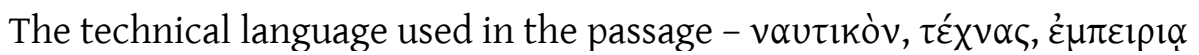

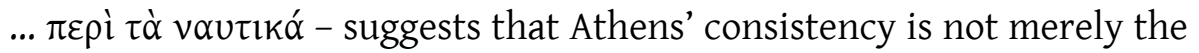
result of singular power, but also of military and logistical skills

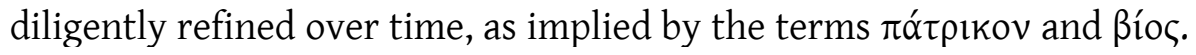
Experience and skill thus work together to create the likelihood (zikós)

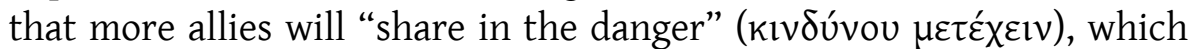
will in turn further facilitate Athenian success. By contrast, Agesilaos' rigid Spartans ostensibly lost their supremacy at the hands of Epaminondas' Thebans, who proved much more malleable to learn by trial and error, adapt, improve, and finally surpass their enemy.$^{90}$ In these examples we find echoes of Thucydides' dictum on the importance of adaptation: "necessity states that, just as with a skill ( $\tau \dot{x} \chi v \eta \zeta)$, improvements always prevail; and though unchanging customs may be best for undisturbed

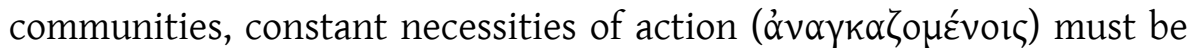
accompanied by the constant improvement of methods

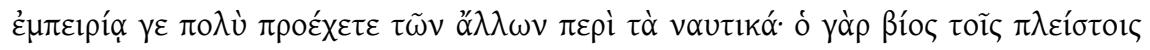

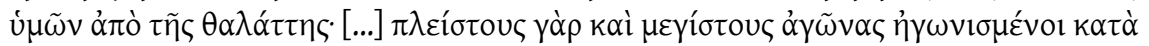

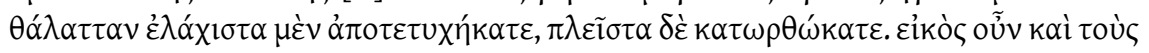

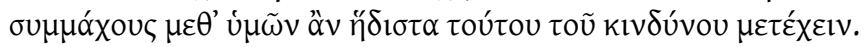

90 Plutarch has Antalkidas bitterly reproach Agesilaos for "having taught those who were neither willing, nor knowledgeable about how to fight." His first defeat was mockingly called "a fine tuition fee that you claim from the Thebans for teaching them how to fight when they did not wish it, and did not even know how." Plut. Ages.

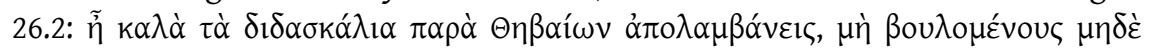

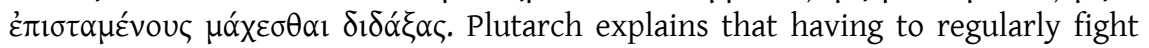
against the Lakedaimonians ultimately forced the Thebans to become more warlike, "such that they were trained ( $\dot{\varepsilon} \gamma v \mu \nu \alpha \sigma \alpha \mu \varepsilon^{\prime}$ ouৎ) through the many campaigns of

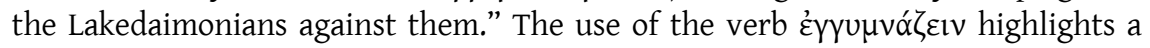
Theban mindfulness of past failures and, at the same time, a constant effort to improve one's chances of success. Purportedly, Agesilaos had contravened an ancient Lykourgan rhetra that specifically prohibited the Spartans to make frequent campaigns against the same enemy, in order that the enemy "might not learn how to make war" (Plut. Ages. 26.3). 


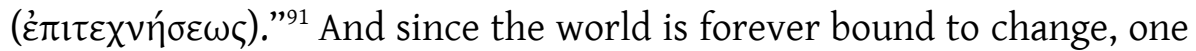
must always remain vigilant, whether enjoying the height of glory or bearing the burden of defeat, because eventually one will be faced with opportunities as well as challenges to one's condition.

\section{CONCLUSION}

This article proposes an alternative approach to the problem of probability in antiquity. By adopting a "frequentist" model based on historical knowledge, we can trace a probabilistic mindset of decision-makers who developed conceptual tools to calculate the likelihoods of occurrence and odds of success in economic, social, and military initiatives. In turn, our discussion on ancient probability will further allow us to explore new avenues for research beyond the realm of ancient science about the formulation of risk in antiquity, and how ancient decision-making bodies understood and undertook contingency planning - both topics of future research. Finally, ancient probability invites us to reconsider the notion that the ancient Greeks were fundamentally "past-oriented", and instead consider a speculative attitude towards a future that could be scrutinized, and even foreseen. Metaphorically speaking, in the valley of ancient history the future was not a sudden and mysterious shout, but an echo carried by the winds of the present hitting the mountains of the past. The Greeks understood that only by knowing the environment could one hope to estimate the echo's path and the distances it traveled.

\section{BIBLIOGRAPHY}

Allen, R.C. 2009. The British Industrial Revolution in Global Perspective. Cambridge.

Austin, M.M. 2006. The Hellenistic World from Alexander to the Roman Conquest: A Selection of Ancient Sources in Translation. 2nd ed. Cambridge.

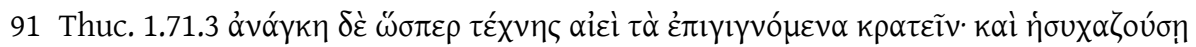

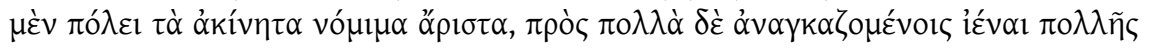

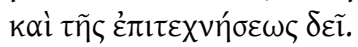


Beard, M. 2011. 'Risk and the Humanities: alea iacta est' in L. Skinns, M. Scott \& T. Cox (eds) Risk. Cambridge, 85-108.

Beerden, K. 2013. World Full of Signs: Ancient Greek Divination in Context. Boston.

Bernstein, P. 1996. Against the Gods: The Remarkable Story of Risk. New York. Bresson, A. 2016. The Making of the Ancient Greek Economy. Princeton.

Bresson, A. 2014. 'Capitalism and the Ancient Greek Economy' in L. Neal \& J. G. Williamson (eds.) The Cambridge History of Capitalism. Cambridge, 43-74.

Bresson, A. \& F. Bresson. 2004. 'Max Weber, la comptabilité rationnelle et l'économie du monde gréco-romain' Les Cahiers du Centre de Recherches Historiques 34, 1-22.

Bru, M-F. \& B. Bru 2018. Les jeux de l'infini et du hazard. Vol. 2. Besançon.

Cairns, D. 2016. 'Metaphors for Hope in Archaic and Classical Greek Poetry' in R.R. Caston \& R.A. Kaster (eds.) Hope, Joy, and Affection in the Classical World. Oxford, 13-44.

Clark, G. 2012. 'Review Essay: The Enlightened Economy. An Economic History of Britain, 1700-1850 by Joel Mokyr' Journal of Economic Literature 50(1), 85-95.

Cohen, E.E. 1992. Athenian Economy and Society: A Banking Perspective. Princeton.

Cooper, C. 2007. 'Forensic Oratory' in I. Worthington (ed.) A Companion to Greek Rhetoric. Malden, MA, 203-20.

Coumet, E. 1970. 'La théorie du hasard est-elle née par hasard?' Annales: Économies, Sociétés, Civilisations 25, 574-98.

Da Silva, S., R. Matsushita \& E. Silveira 2013. 'Hidden power law patterns in the top European football leagues' Physica A: Statistical Mechanics and its Applications 392.21, 5376-86.

Daston, L.J. 1980. 'Probabilistic expectation and rationality in classical probability theory’ Hist. Math. 7, 234-60.

Davies, J.K. 2003. 'Democracy without Theory' in P. Derow \& R. Parker (eds.) Herodotus and his World. Oxford, 319-36.

Duncan-Jones, R. 1990. Structure and Scale in the Roman Economy. Cambridge.

Eidinow, E. 2007. Oracles, Curses \& Risk among the Ancient Greeks. Oxford. Fischhoff, B. \& J. Kadvany. 2011. Risk: A Very Short Introduction. Oxford. 
Franklin, J. 2001. The Science of Conjecture: Evidence and Probability before Pascal. Baltimore, MD.

Frier, B.W. 2007. 'Law and Economic Institutions' in W. Scheidel, I. Morris \& R. Saller (eds.) The Cambridge Economic History of the Greco-Roman World. Cambridge, 113-43.

Frier, B.W. 2000. 'Demography' in A.K. Bowman (ed.) The Cambridge Ancient History. 2nd ed. Vol. 11. Cambridge, 787-816.

Frier, B.W. 1982. ‘Roman Life Expectancy: Ulpian's Evidence' HSCP 86, 213-51.

Gabrielsen, V. 2016. 'Be Faithful and Prosper: Associations, Trust and the Economy of Security’ in K. Dro-Krüpe, S. Föllinger \& K. Ruffing (eds.) Antike Wirtschaft und ihre kulturelle Prägung: The Cultural Shaping of the Ancient Economy. Wiesbaden, 87-111.

Gachet, J. 1990. ‘P. Cairo Zénon IV 59649: un mémoire à Zénon. Trois propositions pour l'exploitation commerciale d'un navire' Cahier de Recherches de l'Institut de Papyrologie et d'Égyptologie de Lille 12, 101-29.

Gagarin, M. 2007. 'Background and Origins: Oratory and Rhetoric before the Sophists' in I. Worthington (ed.) A Companion to Greek Rhetoric. Malden, MA, 27-36.

Gallant, T. 1991. Risk and Survival in Ancient Greece: Reconstructing the Rural Domestic Economy. Stanford.

Garnsey, P. 1988. Famine and Food Supply in the Greco-Roman World. Cambridge.

Giddens, A. 1990. The Consequences of Modernity. Stanford.

Giddens, A. and C. Pierson. 1998. Conversations with Anthony Giddens: Making Sense of Modernity. Redwood City, CA.

Gibbins, D. 2001. 'Shipwrecks and Hellenistic trade' in Z. Archibald, J. Davies, V. Gabrielsen \& G. Oliver (eds.) Hellenistic Economies. New York, 205-32.

Gigerenzer, G. 2002. Reckoning with Risk: Learning to Live with Uncertainty. Toronto.

Hacking, I. 1975. The Emergence of Probability: A Philosophical Study of Early Ideas about Probability, Induction and Statistical Inference. Cambridge.

Hacking, I. 1990. The Taming of Chance. Cambridge.

Hald, A. 2003. A History of Probability and Statistics and Their Applications Before 1750. Hoboken, NJ. 
Kehoe, D. P. 2007. 'The Early Roman Empire: Production' in W. Scheidel, I. Morris \& R. Saller (eds.) The Cambridge Economic History of the GrecoRoman World. Cambridge, 543-69.

Kennedy, G. A. 1995. A New History of Classical Rhetoric. Princeton.

Keyser, P. 2010. 'Science' in A. Barchiesi \& W. Scheidel (eds.) The Oxford Handbook of Roman Studies. Oxford, 859-81.

Keyser, P. \& G. Irby-Massie. 2002. Greek Science of the Hellenistic Era: A Sourcebook. New York.

Keyser, P \& J. Scarborough. 2018. Oxford Handbook of Science and Medicine in the Classical World. Oxford.

Kidd, S. 2020. 'Why Mathematical Probability Failed to Emerge from Ancient Gambling' Apeiron 53.1, 1-25.

Klooster, J.J.H. \& I.N.I. Kuin. 2020. 'Introduction: What is a crisis? Framing versus Experience' in J.J.H. Klooster \& I.N.I. Kuin (eds.) After the Crisis. Remembrance, Re-Anchoring, and Recovery in the Ancient World. London, 3-14.

Kolmogorov, A. 1933. Grundbegriffe der Wahrscheinlichkeitsrechnung. Berlin.

Konijnendijk, R. 2020. 'Risk, Chance and Danger in Classical Greek writing on Battle' Journal of Ancient History 8.2, 175-86.

Konnikova, M. 2020a. 'What Donald Trump Could Learn from Playing Poker' Politico Magazine, 12 July, 2020 = https://www.politico.com/news/magazine/2020/07/12/what-donald-trump-couldearn-from-poker-351055.

Konnikova, M. 2020b. The Biggest Bluff: How I Learned to Pay Attention, Master Myself, and Win. New York.

Koselleck, R. 2006. 'Crisis.' trans. by M. W. Richter. Journal of the History of Ideas 67.2, 357-400.

Meier, C. 1999. The Discovery of Politics. Trans. by D. McLintock. Cambridge, MA.

Meusnier, N. 2008. 'Analyse de Franklin [2001].' Math. Sci. Hum. 184, 10510.

Mokyr, J. 2009. The Enlightened Economy: An Economic History of Britain 17001850. New Haven. 
Morley, N. 2007. 'The Early Roman Empire: Distribution' in W. Scheidel, I. Morris \& R. Saller (eds.) The Cambridge Economic History of the GrecoRoman World. Cambridge, 570-91.

Müller, C. 2011. 'Autopsy of a Crisis: Wealth, Protogenes, and the City of Olbia in c. 200 bc.' in Z.H. Archibald, J.K. Davies \& V. Gabrielsen (eds.) The Economies of Hellenistic Societies. Third to First Centuries BC. Oxford, 324-44.

Narens, L. 2007. Theories of Probability: An Examination of Logical and Qualitative Foundations. Danvers, MA.

Netz, R. 2016. 'Mathematics' in G.L. Irby (ed.) A Companion to Science, Technology, and Medicine in Ancient Greece and Rome. Malden, MA, 79-95.

Neyman, J. 1976. 'The Emergence of Mathematical Statistics: A Historical Sketch with Particular Reference to the United States' in D.B. Owen (ed.) On the History of Statistics and Probability. New York, 149-93.

Ober, J. 2008. Democracy and Knowledge: Innovation and Learning in Classical Athens. Princeton, NJ.

Oliver, G.J. 2007. War, Food, and Politics in Early Hellenistic Athens. Oxford. Pflaumer, P. 2015. 'Estimations of the Roman Life Expectancy Using Ulpian's Table' Joint Statistical Meetings: Social Statistics Section, 2666-80. Sallares, R. 1991. The Ecology of the Ancient Greek World. Ithaca, NY.

Schneider, I. 1980. 'Why do we find the origin of a calculus of probabilities in the seventeenth century?' in J. Hintikka, D. Gruender \& E. Agazzi (eds.) Probabilistic thinking, thermodynamics and the interaction of the history and philosophy of science. Vol. 2. Dordrecht, 3-24.

Shafer, G. 2018. 'Marie-France Bru and Bernard Bru on Dice Games and Contracts' Statistical Science 33, 277-84.

Shafer, G. \& V. Vovk. 2001. Probability and Finance: It's Only a Game! New York.

Sosin, J. 2014. 'Endowments and Taxation in the Hellenistic World' AncSoc 44, 43-89.

Spiegelhalter, D. 2011. 'Quantifying Uncertainty' in L. Skinns, M. Scott \& T. Cox (eds.) Risk. Cambridge, 17-33.

Struck, P. T. 2016. Divination and Human Nature: A Cognitive History of Intuition in Classical Antiquity. Princeton.

Thaler, R. H. 2015. Misbehaving: The Making of Behavioral Economics. New York. 
Vădan, P. 2018. Crisis Management and Socio-Political Risk in the Hellenistic Age. PhD Dissertation. University of Chicago.

Zientek, L. 2014. 'Lucan's Natural Questions: Landscape and Geography in the Bellum Civile.' PhD Dissertation. University of Washington.

Paul Vădan

University of Copenhagen

vadan@hum.ku.dk 